\title{
Ovarian tissue vitrification and heterotopic autologous transplantation in prepubertal Wistar rats
}

\author{
Leticia Wietcovsky ${ }^{1}$, David Til ${ }^{1}$, Rafael Alonso Salvador ${ }^{1}$, Nicole Louise Lângaro Amaral ${ }^{2}$, Alfred Paul Senn ${ }^{1}$, Vera \\ Lucia Lângaro Amaral ${ }^{1}$ \\ ${ }^{1}$ Laboratório de Biotecnologia da Reprodução (LBR), Universidade do Vale do Itajaí (UNIVALI), Itajaí, Santa \\ Catarina, Brazil \\ ${ }^{2}$ Centro Clínico Veterinário (CCV), Itajaí, Santa Catarina, Brazil
}

This manuscript was presented at the CBRA 2017 - São Paulo - Brazil

\begin{abstract}
Objective: To evaluate the efficiency of ovarian tissue heterotopic autografting after vitrification in prepubertal rats.

Methods: Fragments of excised ovaries from prepubertal rats were used after assessing post-warming cellular viability, to determine the best vitrification protocol prior to retroauricular autografting. Pre-pubertal females $(\mathrm{N}=24)$ were castrated and divided into three group: Group 1 fresh ovarian tissue transplantation; Group 2 - vitrified/ warmed tissue transplantation; Group 3 - bilateral oophorectomy without transplantation. The ovarian fragments were exposed to solutions from the Ingamed $^{\circledR}$ commercial kit, allocated in bacteriological loops and immersed in liquid nitrogen. Sixty days after transplantation, a vaginal mucus sample was collected for cytology tests, followed by sacrificing the animal, performing a cardiac puncture for collecting a blood sample to determine luteinizing hormone and estradiol levels, and excision of the transplanted fragment for histology tests.

Results: Vaginal cytology revealed that $87.5 \%$ of females from groups 1 and 2 had estrus while all females in Group 3 remained in diestrus. The mean $\mathrm{LH}$ value in groups $1(0.08 \mathrm{mIU} / \mathrm{mL})$ and $2(0.34 \mathrm{mIU} / \mathrm{mL})$ were statistically different from that of Group $3(2.27 \mathrm{mIU} / \mathrm{mL})$. E2 values did not differ between the groups. The histological analysis of Group 1 excised grafts versus those from Group 2 showed a higher percentage of primary follicles $(62.5 \%$ vs. $12.5 \%)$, developing follicles (75\% vs. $25 \%$ ), corpus luteum $(37.5 \%$ vs. $12.5 \%)$ and stromal region (100\% vs. $87.5 \%)$
\end{abstract}

Conclusion: This study indicated that pre-pubertal ovarian tissue vitrification can be used to preserve fertility and to restore endocrine function in castrated rats.

Keywords: cryopreservation, ovarian tissue, vitrification, autologous heterotopic transplantation, restoration of endocrine function

\section{INTRODUCTION}

Infertility, which affects the human population worldwide, has significant psychological consequences (Brezina et al., 2015), and it is considered a public health problem by the World Health Organization (WHO) (Van der Poel, 2012). Among the causes of infertility, neoplasia and their associated treatments, such as chemotherapy and radiotherapy, exert irreversible cytotoxic effects on male and female gonads, which eventually lead to hormonal and reproductive failure (Schunemann Jr et al., 2011; Almodin \& Costa, 2014). Considering that the estimated 2016-2017 occurrence of cancer in Brazil will be around 600,000 new cases (INCA, 2015), equally divided between men and women, and that anticancer treatments are increasingly efficient, it becomes necessary to offer these patients the possibility to preserve their fertility. According to the recommendations from the American Society of Clinical Oncology, some of the proven effective methods currently available for preserving female fertility are embryo cryopreservation, oophoropexy prior to localized radiotherapy, and oocyte cryopreservation (Loren et al., 2013).

For many oncologists, cryopreservation of oocytes and embryos may be unfeasible, mainly due to the need for hormonal stimulation to obtain oocytes and the ensuing delayed cancer treatment onset. Furthermore, it is not usable in young patients who have not initiated puberty or to adult women who suffer from hormone-dependent cancer (Moura et al., 2015). Alternatively, the association of cryopreservation and ovarian tissue reimplantation can be performed at any time during the menstrual cycle and does not require hormonal stimulation (Donnez et al., 2004). This technique is still new for young cancer patients, as the first live birth after cryopreserved ovarian tissue before menarche followed by transplantation at adulthood occurred only recently (Demeestere et al., 2015).

There are two main cryopreservation techniques: the so-called slow freezing method, which requires gradual cooling ramps and low concentrations of cryoprotectants, and the vitrification method, that consists in ultrafast cooling of the biological material in the presence of high concentrations of cryoprotective agents (Niemann, 1991; Castro et al., 2011). The slow freezing technique has been routinely used for ovarian tissue cryopreservation (Newton et al., 1996; Oktay \& Karlikaya, 2000), however, the vitrification technique has been shown to have equal or greater efficiency in ovarian tissue preservation than the slow freezing protocol (Silva, 2014). The first success with a live birth in humans was obtained with the slow freezing technique and orthotopic transplantation of cryopreserved ovarian tissue in an adult patient (Donnez et al., 2004).

The transplantation can be classified according to the implantation site, as orthotopic, in which the tissue is transplanted to its original site, or heterotopic when the tissue is transplanted to a region other than its original one (Sonmezer \& Oktay, 2004). The first one enables a possible spontaneous gestation; whereas heterotopic transplantation requires the use of ancillary techniques, such as in-vitro culture of ovarian follicles followed by oocyte maturation and in-vitro fertilization, enabling embryo production and transfer (Lunardi et al., 2013). Several studies have been carried out to try to find the best place to perform ovarian auto-transplantation (d'Acampora et al., 2004; Donnez et al., 2013). Experimentally, we may consider sites such as: underneath the renal capsule (Oktay \& Karlikaya, 2000), the retroperitoneum (d'Acampora et al., 2004) in rats, subcutaneously (Scalercio et al., 2015) and iliac fossa and omentum (Igarashi et al., 2010) in non-human primates.

To date, about 86 live births have been recorded in the literature, either in peer-reviewed journals or in conference proceedings (Jadoul et al., 2017). Among these, only two births came from vitrified ovarian tissue (Suzuki et al., 
2015), probably because vitrification is a more recently established technique, and there was no time to perform a transplantation in a clinically healthy patient after oncological treatment within the considered period.

Several techniques can be used to evaluate the competence of the ovarian graft post-cryopreservation. In addition to DNA fragmentation, the technique usually employed is the morphological analysis of the tissue through classical histology by staining with hematoxylin-eosin, due to its low cost and ease of execution. In a smaller scale, fluorescence and electron microscopy, cytological analysis of vaginal smears in animals, serum levels of pituitary and gonadal hormones, and follicular in vitro culture are also used (Rodriguez-Wallberg \& Oktay, 2014).

With the increase in the number of specialized centers providing care to women in search of alternatives for fertility preservation, the development of more effective protocols is fundamental to successfully put into practice ovarian tissue transplantation and cryopreservation techniques. Therefore, the objective of this study is to evaluate heterotopic autografting of pre-vitrified ovarian tissue efficiency using prepubertal rats as experimental models.

\section{MATERIALS AND METHODS}

\section{Animals}

For this study, 31 female rats (Wistar) 30-60 days old were obtained from the vivarium of the University of "Vale do Itajaí - UNIVALI, SC". This study was approved by the Ethics Committee on Animal Use (CEUA) under number 003/16.

\section{Vitrification protocols}

To determine the best vitrification protocol, 18 ovarian fragments from Wistar rats (Rattus norvegicus) were obtained from 7 females in pre-pubertal age (30 to 60 days). After sacrifying the animals in a $\mathrm{CO}_{2} / \mathrm{O}_{2}$ chamber, oophorectomy was performed and the ovaries were cut into $1 \mathrm{~mm}$-thick fragments. One of the dissected fragments was submitted to follicular viability using Trypan blue (Sigma, São Paulo, Brazil) vital stain (0.4\%) (Fauque et al., 2007). Unstained follicles were considered viable. The other fragments were divided and submitted to three vitrification protocols.

Protocol 1: the fragments were exposed for $25 \mathrm{~min}$ utes to the vitrification solution (VS1), composed of $7.5 \%$ dimethylsulfoxide (DMSO, Nuclear, São Paulo, Brazil) and $7.5 \%$ ethylene glycol (EG, Sigma, São Paulo, Brazil), and subsequently to a vitrification solution (VS2) containing 20\% DMSO, 20\% EG and 0.4M sucrose (Sigma, São Paulo, Brazil) for 15 minutes. Fragment warming was carried out using $1 \mathrm{M}$ and $0.5 \mathrm{M}$ sucrose for 1 and 5 minutes respectively, followed by 10 minutes in Modified-HTF (Irvine Scientific $^{\circledR}$, Santa Ana, USA) (adapted from Kagawa et al., 2009).

Protocol 2: the fragments were exposed to the same VS1 solution used in protocol 1, but for 10 minutes only, followed by VS2 vitrification solution containing $15 \%$ DMSO, $15 \%$ EG and $0.4 \mathrm{M}$ sucrose for 2 minutes. For warming purposes, the fragments were exposed to $1 \mathrm{M}$, $0.5 \mathrm{M}$ and $0.25 \mathrm{M}$ sucrose for 5 minutes each (adapted from Chen et al., 2006).

Protocol 3: the fragments were exposed to a balancing VI-1 solution containing $7.5 \%$ EG and $7.5 \%$ DMSO in buffered medium, supplemented with $20 \%$ synthetic serum for 25 minutes (Ingamed ${ }^{\circledR}$ Trade Kit, Maringá, Brazil). The fragments were then transferred to a vitrification solution (VI-2), composed of $15 \%$ EG, $15 \%$ DMSO plus $0.5 \mathrm{M}$ sucrose, in buffered medium, supplemented with $20 \%$ synthetic serum for 15 minutes. Warming was performed with a DV- 1 solution, containing $1 \mathrm{M}$ sucrose and $20 \%$ synthetic serum in buffered medium for 5 minutes, followed by
DV-2, containing $0.5 \mathrm{M}$ sucrose and $20 \%$ synthetic serum in buffered medium for 5 minutes. Finally, the fragments were exposed to a balancing DV-3 solution, composed of buffered medium and $20 \%$ synthetic serum for 10 minutes (adapted from Wang et al., 2008).

Vitrification: The whole vitrification procedure was performed on an ice sheet, so that the temperature remained between $6^{\circ} \mathrm{C}$ and $8^{\circ} \mathrm{C}$ (Amorim et al., 2009). Vitrification was performed using sterile $230 \mathrm{~mm}$ bacterial inoculation loops, which were reduced in length to about $2 \mathrm{~cm}$ (Olen ${ }^{\circledR}$, Teratec, São Paulo, Brazil). The balanced fragments were deposited inside the loop and immediately immersed in liquid nitrogen $\left(-196^{\circ} \mathrm{C}\right)$ (Figure 1$)$.

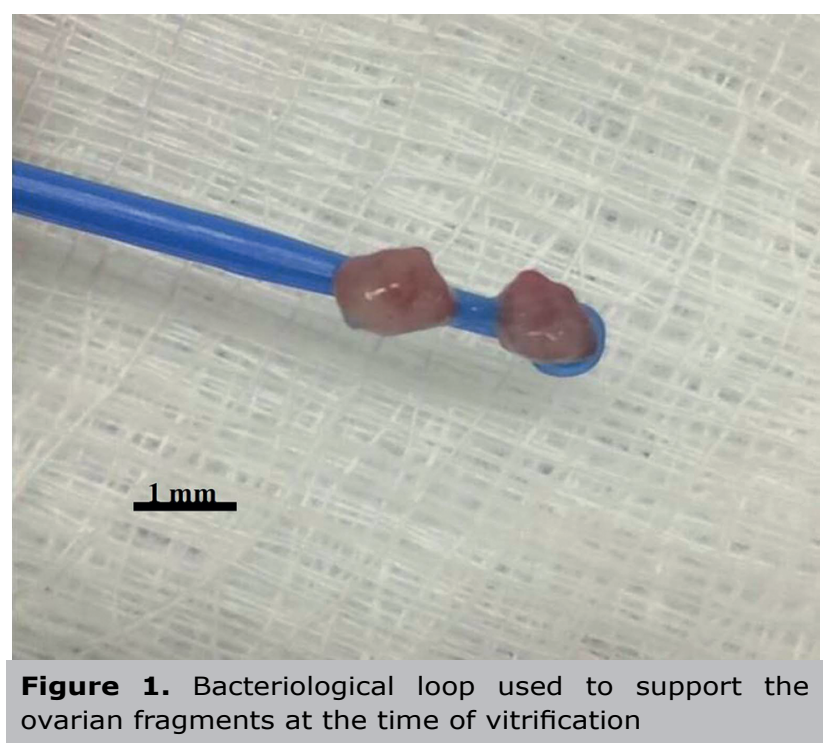

Warming: The first devitrification solution from each protocol was kept at $37^{\circ} \mathrm{C}$ and the others at room temperature $\left(22 \pm 2^{\circ} \mathrm{C}\right)$, according to the above-mentioned protocols. After warming, the cell viability was again checked using the vital stain trypan blue.

\section{Autologous and heterotopic transplantation}

Protocol 3 was used to vitrify the ovarian fragments, prior to transplantation, because this protocol yielded the best recovery of viable cells (see Results).

The pre-pubertal Wistar female rats were divided into 3 groups of 8 animals. Group 1: transplantation of fresh ovarian graft in the retroauricular region. Group 2: transplantation of vitrified/warmed ovarian tissue to the retroauricular region. Group 3: bilateral oophorectomy without ovarian tissue reimplantation. For oophorectomy, the animals were anesthetized with a combination of $10 \%$ ketamine hydrochloride $(40 \mathrm{mg} / \mathrm{kg})+2 \%$ xylazine hydrochloride $(20 \mathrm{mg} /$ $\mathrm{kg})+1 \%$ acepromazine $(3 \mathrm{mg} / \mathrm{kg})$ intraperitoneally (IP). For the animals in Group 1, the fresh fragment of the removed ovarian tissue was transferred immediately to the retroauricular region, through an incision of approximately $50 \mathrm{~mm}$, with insertion of the graft and subsequent access cauterization. For animals in Group 2, reimplantation was performed in the same way as in Group 1, but after 20 days of oophorectomy and vitrification/warming of the fragments. After the surgical procedures in the groups, $1 \%$ ketoprofen analgesic $(5 \mathrm{mg} / \mathrm{kg}$ ) was administered subcutaneously. After surgery, the animals were kept in their usual conditions for 60 days. The animal health was ascertained during the handling of the habitats, feeding, and cleaning of the cages. 
During the four days prior to slaughtering, vaginal cytology was performed to evaluate the estrous cycle phase, washing the vaginal canal with saline daily. The smear was stained with the panoptic kit (RenyLab ${ }^{\circledR}$, Barbacena, MG, Brazil). The presence or absence of leukocytes, nucleated and keratinized cells (Figure 2) was observed to characterize each phase of the estrous cycle; i.e., diestrus, proestrus, estrous and metestrus (Marcondes et al., 2002). The animals were killed in a $\mathrm{CO}_{2} / \mathrm{O}_{2}$ chamber and a cardiac puncture was performed for blood collection and determination of serum Luteinizing hormone (LH) and estradiol (E2) levels.

The ovarian fragments were removed from the graft sites and submitted to histological analysis with hematoxylin and eosin staining. The slides with the histological sections were analyzed morphologically and for the presence or absence of primary follicles, developing follicles, corpus luteum, pyknosis and stromal region.

\section{Hormone analysis}

LH and E2 were analyzed by the Laboratório Escola de Análises Clínicas (LEAC/UNIVALI) using chemiluminescence methods (ADVIA-Centaur, Brazil).

\section{Statistical analysis}

The data were submitted to statistical analysis (Instat, GraphPad Software, USA) using ANOVA and Tukey's multiple mean comparison among the three groups. The significance level was set at $p<0.05$.

\section{RESULTS}

In a preliminary phase, three vitrification protocols were tested in order to optimize the concentration of the cryoprotectants (DMSO, EG, sucrose) and the exposure time to these compounds during the pre- and post-vitrification processes. Cell viability using trypan blue staining was used to determine which of these protocols yielded the highest survival rates. Cell viability after vitrification with protocols 1, 2 and 3 were $81.3 \%, 90.8 \%$ and $96.3 \%$, respectively (data not shown). On this basis, protocol 3 was used for the transplantation experiments.
Sixty days after the surgical transplantation of the ovarian tissue, the estrus cycle phase was determined in the transplanted (Group 1 and Group 2) and non-transplanted castrated females (Group 3 ) on the day of slaughtering. Vaginal swabs were collected from all females immediately after death. The stained vaginal smears were examined under 400x magnification and the stage of the estrous cycle determined. In both Groups 1 and 2, the presence of an estrous cycle was confirmed in 7 out of 8 females (87.5\%) (Figure 2, I-II). All females from Group 3, which only had their ovaries removed and were not transplanted, remained in the diestrus stage (Table 1 ).

LH and E2 levels were also measured in each animal and the results are presented in Tables 1 and 2 . In groups 1 and 2 , the LH levels were $\leq 0.16 \mathrm{mIU} / \mathrm{mL}$ and $\leq 0.78$ $\mathrm{mIU} / \mathrm{mL}$, respectively. In Group 3, the LH levels were higher: between $0.75 \mathrm{mIU} / \mathrm{mL}$ and $5.43 \mathrm{mIU} / \mathrm{mL}$. Conversely, E2 levels were higher in Groups 1 and 2, with mean values of $23.9 \pm 4.8 \mathrm{pg} / \mathrm{mL}$ and $27.4 \pm 4.3 \mathrm{pg} / \mathrm{mL}$, respectively; about twice as much as what was measured in Group 3: $14.3 \pm 1.7 \mathrm{pg} / \mathrm{mL}$ (Table 2).

In the histological analysis of the grafted tissue, the presence or absence of pycnosis (Figure 3-I), corpus luteum (Figure 3-II), primary follicle (Figure 3-III), developing follicle (Figure 3- III) and stroma (Figure 3-III) were considered. The analysis of the histological sections of Group 1 vs Group 2 showed a higher percentage of primary follicles $(62.5 \%$ vs. $12.5 \%)$, developing follicles $(75 \%$ vs. $25 \%)$, corpus luteum ( $37.5 \%$ vs. $12.5 \%)$ and stromal region ( $100 \%$ vs. $87.5 \%)$. These two groups also showed pycnotic nuclei, not found in the histological sections of the fragments analyzed before the tissue was re-implanted (Table 3).

In addition, in all histological sections that confirmed the presence of some ovarian structure, it was possible to identify graft neovascularization (Figure 3-III). A vitrified graft fragment was surgically removed after 60 days of transplantation and, after dissection, it revealed the presence of developing follicles containing oocytes with good morphological quality (Figure 3-IV).

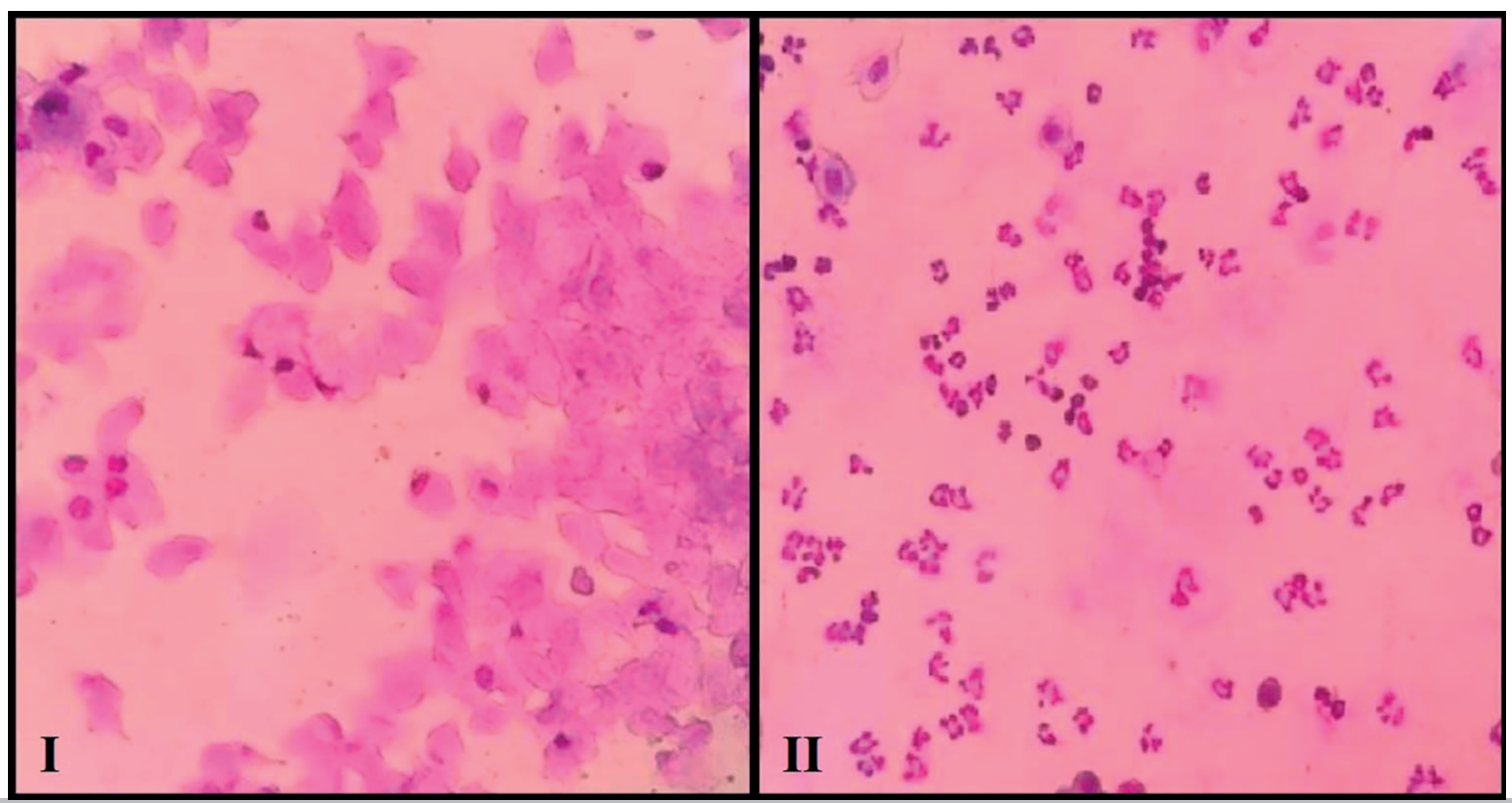

Figure 2. Examples of various stages of vaginal histology observed after transplantation. I - Estrous stage: keratinized cells typical of this stage (400x); II - Diestrous stage: leukocytes and nucleated cells typical of this stage (400x). 
Table 1. Estrus cycle phase on the last day of collection of vaginal cytology and individual serum $\mathrm{LH}(\mathrm{mIU} / \mathrm{mL})$ and $\mathrm{E} 2$ $(\mathrm{pg} / \mathrm{mL})$ values in the three groups. $\mathrm{M}$ : metestrus, D: diestrus, E: estrous, P: proestrus.

\begin{tabular}{|l|c|c|c|c|c|c|c|c|c|}
\hline & \multicolumn{3}{|c|}{ Group 1 } & \multicolumn{3}{c|}{ Group 2 } & \multicolumn{3}{c|}{ Group 3 } \\
\cline { 2 - 11 } & Phase & LH & E2 & Phase & LH & E2 & Phase & LH & E2 \\
\hline $\mathbf{1}$ & M & 0.07 & 19.49 & M & 0.56 & 26.95 & D & 2.1 & 11.8 \\
\hline $\mathbf{2}$ & D & 0.07 & 11.8 & M & 0.6 & 20.33 & D & 1.33 & 23.95 \\
\hline $\mathbf{3}$ & E & 0.16 & 13.17 & E & 0.07 & 17.69 & D & $*$ & $*$ \\
\hline $\mathbf{4}$ & E & 0.07 & $*$ & D & 0.78 & 30.45 & D & 2.63 & 11.8 \\
\hline $\mathbf{6}$ & P & 0.07 & 42.34 & M & 0.08 & 20.75 & D & 2.68 & 11.8 \\
\hline $\mathbf{7}$ & M & 0.07 & 24.53 & M & 0.07 & 25.41 & D & 5.43 & 11.8 \\
\hline $\mathbf{8}$ & P & 0.07 & 31.91 & E & 0.41 & 21.9 & D & 0.75 & 15.76 \\
\hline
\end{tabular}

* Analysis not performed due to insufficient serum for analysis.

\begin{tabular}{|c|c|c|}
\hline Groups & LH (mUI/mL) & $E 2(\mathrm{pg} / \mathrm{mL})$ \\
\hline $\mathbf{1}$ & $0.08 \pm 0.01^{a, c}$ & $23.87 \pm 4.78$ \\
\hline 2 & $0.34 \pm 0.10^{a, b}$ & $27.42 \pm 4.32^{\mathrm{d}}$ \\
\hline 3 & $2.27 \pm 0.60^{\mathrm{b}, \mathrm{c}}$ & $14.28 \pm 1.70^{d}$ \\
\hline
\end{tabular}

a $p<0.05$, b,c $p<0.02,{ }^{\text {d }} p<0.02$

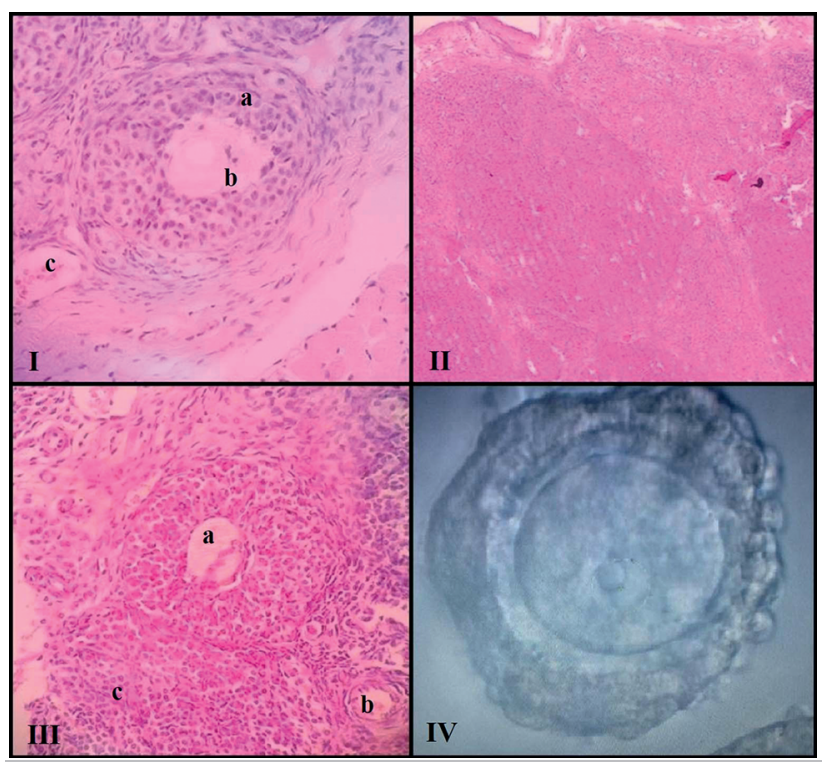

Figure 3. Example of various stages of follicular development. I - Pycnosis (a), developing follicle (b), vascularization (c); II - Corpus luteum; III - Developing follicle (a), primary follicle (b), stroma (c); IV - Prophase I oocyte

\section{DISCUSSION}

Due to the high complexity of the ovarian structure, tissue survival depends not only on the cooling rates during the cryopreservation process but also on thawing and the removal of cryoprotectants (Thomaz et al., 2005). In this context, several protocols were tested with the objective of improving the efficiency of ovarian tissue cryopreservation. Three vitrification protocols were tested, the one that demonstrated the greatest cell viability after devitrification was used for the subsequent heterotopic autograft. Viability was tested using trypan blue, a dye used to evaluate cell membrane integrity; i.e., stained follicles have damaged membranes (Jewgenow, 1998). The same dye was used to evaluate the toxicity of cryoprotectants in sheep, demonstrating greater follicular viability when EG and DMSO cryoprotectants were used (Santos et al., 2006). In human ovary fragments, the viability of primordial and primary follicles was lower after freezing $(71.9 \%)$ than before the procedure (87.3\%) (Fauque et al., 2007). In addition, in fresh tissue, a follicular death of $12.7 \%$ was associated with the mechanical trauma caused by tissue sectioning. In our study, this mechanical damage occurred to a lesser extent and was estimated at $3.67 \%$. An increasing exposure time to propanediol (PROH) favors a decrease in the number of viable follicles using slow freezing, an indication that there is a limit to cell dehydration and to metabolic resistance against the toxic effects of the cryoprotectants (Gonçalves et al., 2012). Confronting our results to those published in the literature, it may be concluded that the decline in follicle viability found in our study can be considered normal.

In our study, the 25-minute exposure to the solutions containing DMSO and EG at $7.5 \%$ provided good tissue permeation and a better recovery of living cells after warming. On the other hand, shorter times in the equilibrium solution did not enable adequate permeation.

For the vitrification technique to work well, it is important that the volume of the vitrification solution that surrounds the fragment be as small as possible when entering liquid nitrogen (Wang et al., 2008). In this context, the fragment packaging method interferes with the cryopreservation technique efficacy. Thomaz et al. (2005), using rabbit ovaries, introduced the sections of tissue in straws using the slow freezing protocol, and found the survival of only primordial follicles. Using the same animal model, Almodin et al. (2004) vitrified the ovarian fragments in cryogenic tubes and obtained spontaneous pregnancies in all animals in which the cryopreserved tissue reimplantation was performed. Wang et al. (2008) were successful using human ovary cortex and rat ovary when they allocated the fragments into acupuncture needles, to maximize and simplify the vitrification process. In this study, the ovarian fragments were placed in bacteriological loops and stored in cryogenic tubes, obtaining a rate of $100 \%$ recovery of the fragments after thawing. In addition, the easy handling and reduction of the excess volume of the vitrification solution, essential for the success of the technique, have been verified. After reviewing the literature on 


\begin{tabular}{|c|c|c|c|c|c|}
\hline Group & Pyknosis & Primary follicle & $\begin{array}{l}\text { Developing } \\
\text { follicle }\end{array}$ & Corpus luteum & Stroma \\
\hline $\mathbf{1}$ & $100 \%(8 / 8)$ & $100 \%(8 / 8)$ & $75 \%(6 / 8)$ & $37.5 \%(3 / 8)$ & $100 \%(8 / 8)$ \\
\hline 2* & $0(0 / 8)$ & $87.5 \%(7 / 8)$ & $100 \%(8 / 8)$ & $0(0 / 8)$ & $100 \%(8 / 8)$ \\
\hline 2 & $87.5 \%(7 / 8)$ & $12.5 \%(1 / 8)$ & $25 \%(2 / 8)$ & $12.5 \%(1 / 8)$ & $87.5 \%(7 / 8)$ \\
\hline
\end{tabular}

the subject, no study was found mentioning the type of device used in our study. We believe this type of packaging is a new viable option for cryopreservation of ovarian tissue.

Considering the graft experiments, several studies were carried out in an attempt to find the best anatomical site to perform the ovarian implant (Oktay \& Karlikaya, 2000; d'Acampora et al., 2004; Igarashi et al., 2010). According to Donnez et al. (2013), negative aspects in the use of heterotopic transplantation are the differences in temperature, pressure, and vascularization between the heterotopic site and the donor area. In this study, heterotopic transplantation was performed in the retroauricular region, which facilitates visualization of the graft and has adequate vascularization. In a long-term study involving women, endocrine recovery after heterotopic transplantation was demonstrated by the return of hormonal function using vaginal cytology in $87.5 \%$ of the women (Kim, 2012).

In rodents, the study of vaginal cytology is effective in evaluating ovarian function due to short estrus periods (4-5 days) and easy cell characterization (Jafarey \& Jaffri, 2016). In each phase of the estrous cycle, there are characteristic cells and this change is due to the influence of the hormones that are active in each phase. In the diestrus phase, identified in all the females of Group 3, a higher level of LH and a lower level of E2 were found when compared to the other groups. The different LH values recorded for the different females can be justified by the pulsatile form of release of this hormone (Kim, 2012). However, E2, a marker of ovarian function, is $90 \%$ synthesized by the follicles, but it can also be produced through an extra-glandular conversion of testosterone and androstenedione (Saraiva et al., 2010). The insufficient production of E2 at this stage explains the lack of negative feedback and the increased LH production. On the other hand, E2 levels were higher in ovarian transplant groups, demonstrating that there was ovarian activity, since E2 is synthesized within the developing follicles and these were present in the histological analysis. Hormone levels are usually restored when the vascular network of the implant is already established and a percentage of tissue remains viable with active secretory cells.

Ovarian transplantation aims to recover hormonal and reproductive functions, and may be an alternative for menopausal women who have cryopreserved their ovarian tissue during their reproductive age. However, transplantation of the tissue fragments is the main factor contributing to the loss of a considerable number of follicles and it is directly related to the time necessary for the reestablishment of blood supply, a delay which may compromise graft survival. The longer the time to angiogenesis, the shorter the graft survival (Jafarey \& Jaffri, 2016). The greatest difficulty is in the immediate post-reimplantation period, when the risk of ischemia is higher leading to irreversible follicular loss (Newton et al., 1996). Messias (2016), using prepubertal rats, found ovarian degeneration in all animals receiving grafts, since the presence of necrotic and fibrotic areas was seen in the histology of the fragments, probably caused by tissue ischemia. In the present study, we found pyknosis, represented by condensed nuclei smaller than normal, with a lighter halo around the nucleus, a sign of cellular apoptosis (Santos et al., 2012). Oliveira (2011), also using rats as a model, found pyknosis in fresh and cryopreserved transplanted tissue, which corroborates the present study. In addition to the cryopreservation process itself, tissue manipulation can also cause damage.

\section{CONCLUSION}

This study shows that autologous heterotopic ovarian transplantation is a feasible approach to testing the conditions of ovarian cryopreservation. We present a new and simple tool for ovarian vitrification, with promising results. Although our study, as well as all similar studies published so far, showed that there is significant tissue loss associated with the vitrification and transplantation procedures, cryopreservation of ovarian tissue remains an important alternative for some women. The development of more efficient cryopreservation techniques should be encouraged.

\section{ACKNOWLEDGEMENTS}

Special thanks to Prof. Dr. David Rivero Tames, Head of the UNIVALI-SC Histology Lab, for his help in analyzing the ovarian tissue histology.

\section{CONFLICT OF INTEREST}

All authors state that they have no conflict of interest.

\section{Corresponding author:}

Vera Lucia Lângaro Amaral

Laboratorio de Biotecnologia da Reprodução

Universidade do Vale do Itajaí (UNIVALI)

Itajaí, SC, Brazil

Email:veralucia@univali.br

\section{References}

Almodin CG, Costa RR, eds. Criopreservação em Reprodução. Maringá: Dental Press; 2014.

Almodin CG, Minguetti-Câmara VC, Meister $H$, Ceschin AP, Kriger E, Ferreira JO. Recovery of natural fertility after grafting of cryopreserved germinative tissue in ewes subjected to radiotherapy. Fertil Steril. 2004;81:160-4. PMID: 14711560 DOI: 10.1016/j.fertnstert.2003.05.023

Amorim CA, Van Langendonckt A, David A, Dolmans MM, Donnez J. Survival of human pre-antral follicles after cryopreservation of ovarian tissue, follicular isolation and in vitro culture in a calcium alginate matrix. Hum Reprod. 2009;24:92-9. PMID: 18815120 DOI: $10.1093 /$ humrep/den343

Brasil. Instituto Nacional de Câncer - INCA. Estimativa 2016: Incidência de Câncer no Brasil. Rio de Janeiro: INCA; 2015. Available at: http://www.inca.gov.br/ estimativa/2016/sintese-de-resultados-comentarios.asp. Accessed: 19/12/2017. 
Brezina PR, Kutteh WH, Bailey AP, Ding J, Ke RW, Klosky $\mathrm{JL}$. Fertility preservation in the age of assisted reproductive technologies. Obstet Gynecol Clin North Am. 2015;42:3954. DOI: $10.1016 /$ j.ogc.2014.09.004

Castro VS, Carvalho AA, Silva CMG, Faustino LR, Figueiredo JR, Rodrigues APR. Agentes crioprotetores intracelulares: características e utilização na criopreservação de tecido ovariano e oócitos de tecido ovariano e oócitos. Acta Sci Vet. $2011 ; 39: 1-17$.

Chen SU, Chien CL, Wu MY, Chen TH, Lai SM, Lin CW, Yang YS. Novel direct cover vitrification for cryopreservation of ovarian tissues increases follicle viability and pregnancy capability in mice. Hum Reprod. 2006;21:2794-800. PMID: 16982660 DOI: $10.1093 /$ humrep/del210

d'Acampora AJ, Tramonte R, Manoel FS, Schmidt RR, Muller $C T$, Silva HT, Oliveira A, Raymundi SD. Histological analysis of the viability of half ovary autologous transplantation in retroperitoneal of rats. Acta Cir Bras. 2004;19:360-9. DOI: $10.1590 / \mathrm{S} 0102-86502004000400007$

Demeestere I, Simon $P$, Dedeken L, Moffa $F$, Tsépélidis S, Brachet C, Delbaere A, Devreker F, Ferster A. Live birth after autograft of ovarian tissue cryopreserved during childhood. Hum Reprod. 2015;30:2107-9. PMID: 26062556 DOI: $10.1093 /$ humrep/dev128

Donnez J, Dolmans MM, Demylle D, Jadoul P, Pirard C, Squifflet J, Martinez-Madrid B, van Langendonckt $A$. Livebirth after orthotopic transplantation of cryopreserved ovarian tissue. Lancet. 2004;364:1405-10. PMID: 15488215 DOI: $10.1016 / S 0140-6736(04) 17222-X$

Donnez J, Dolmans MM, Pellicer A, Diaz-Garcia C, Sanchez Serrano M, Schmidt KT, Ernst E, Luyckx V, Andersen CY. Restoration of ovarian activity and pregnancy after transplantation of cryopreserved ovarian tissue: a review of 60 cases of reimplantation. Fertil Steril. 2013;99:1503-13. PMID: 23635349 DOI: 10.1016/j.fertnstert.2013.03.030

Fauque P, Ben Amor A, Joanne C, Agnani G, Bresson JL, Roux C. Use of trypan blue staining to assess the quality of ovarian cryopreservation. Fertil Steril. 2007;87:1200-7. PMID: 17307173 DOI: 10.1016/j.fertnstert.2006.08.115

Gonçalves RFB, Lunardi FO, Alves AMCV, Araújo VR, Figueiredo JR, Campello CC, Rodrigues APR. Sheep ovarian tissue slow freezing using 1,2-propanediol (PROH) as cryoprotectant followed by short-term in vitro culture. Ciênc Anim. 2012;22:3-16.

Igarashi S, Suzuki N, Hashimoto S, Takae S, Takenoshita M, Hosoi $Y$, Morimoto $Y$, Ishizuka B. Heterotopic autotransplantation of ovarian cortex in cynomolgus monkeys. Hum Cell. 2010;23:26-34. PMID: 20590916 DOI: $10.1111 / \mathrm{j} .1749-0774.2010 .00081 . x$

Jadoul P, Guilmain A, Squifflet J, Luyckx M, Votino R, Wyns $C$, Dolmans MM. Efficacy of ovarian tissue cryopreservation for fertility preservation: lessons learned from 545 cases. Hum Reprod. 2017;32:1046-54. PMID: 28333228 DOI: 10.1093/humrep/dex040

Jafarey R, Jaffri SARS. Study on the Estrous Cycle Regularity of Cryopreserved Rat OvarianTissues after Heterotopic Transplantation. Open J Obstet Gynecol. 2016;6:293-8. DOI: $10.4236 /$ ojog.2016.65037
Jewgenow K. Role of media, protein and energy supplements on maintenance of morphology and DNA-synthesis of small preantral domestic cat follicles during short-term culture. Theriogenology. 1998;49:1567-77. PMID: 10732020 DOI: $10.1016 /$ S0093-691X(98)00102-2

Kagawa N, Silber S, Kuwayama M. Successful vitrification of bovine and human ovarian tissue. Reprod Biomed Online. 2009;18:568-77. PMID: 19401001 DOI: $10.1016 / \mathrm{S} 1472-6483(10) 60136-8$

Kim SS. Assessment of long term endocrine function after transplantation of frozen-thawed human ovarian tissue to the heterotopic site: 10 year longitudinal follow-up study. J Assist Reprod Genet. 2012;29:489-93. PMID: 22492223 DOI: $10.1007 / \mathrm{s} 10815-012-9757-3$

Loren AW, Mangu PB, Beck LN, Brennan L, Magdalinski AJ, Partridge AH, Quinn G, Wallace WH, Oktay K; American Society of Clinical Oncology. Fertility preservation for patients with cancer: American Society of Clinical Oncology clinical practice guideline update. J Clin Oncol. 2013;31:2500-10. PMID: 23715580 DOI: 10.1200/JCO.2013.49.2678

Lunardi FO, Ferreira ISB, Bernuci MP. Banco de Ovário: Uma Alternativa para Preservação de Fertilidade em Mulheres Diagnosticadas com Câncer. Rev Saude Pesqui. 2013;6:525-32.

Marcondes FK, Bianchi FJ, Tanno AP. Determination of the estrous cycle phases of rats: some helpful considerations. Braz J Biol. 2002;62:609-14. PMID: 12659010 DOI: 10.1590/S1519-69842002000400008

Moura BVCS, Penna LFVS, Lopes MHC, Soares W, Souza JHK. Métodos de preservação de fertilidade: revisão da literatura. Braz J Surg Clinical Res. 2015;13:56-64.

Messias CB. Transplante heterotópico autólogo de tecido ovariano pré-púbere criopreservado em ratas ooforectomizadas [Thesis]. Programa de Pós-Graduação em Ciências da Saúde: Ginecologia e Obstetrícia. Porto Alegre: Universidade Federal do Rio Grande do Sul; 2016. Available at: http://www.lume.ufrgs.br/bitstream/ handle/10183/148134/000998953. pdf? sequence $=1$. Accessed: 19/12/2017.

Newton H, Aubard Y, Rutherford A, Sharma V, Gosden R. Low temperature storage and grafting of human ovarian tissue. Hum Reprod. 1996;11:1487-91. PMID: 8671490 DOI: $10.1093 /$ oxfordjournals.humrep.a019423

Niemann H. Cryopreservation of ova and embryos from livestock: Current status and research needs. Theriogenology. 1991;35:109-24. DOI: 10.1016/0093-691X(91)90151-3

Oktay K, Karlikaya G. Ovarian function after transplantation of frozen, banked autologous ovarian tissue. $N$ Engl J Med. 2000;342:1919. PMID: 10877641 DOI: 10.1056/NEJM200006223422516

Oliveira ICL. Comparative analysis among different cryopreservation systems of ovarian tissues in female Wistar rats. [Thesis]. Programa de Pós-Graduação Ciências Veterinárias. Faculdade de Veterinária. Porto Alegre: Universidade Federal do Rio Grande do Sul; 2011. Available at: http://www.lume.ufrgs.br/bitstream/ handle/10183/32135/000786681. pdf?sequence $=1 \&$ localeattribute=en. Accessed 19/12/2017. 
Rodriguez-Wallberg KA, Oktay K. Fertility preservation during cancer treatment: clinical guidelines. Cancer Manag Res. 2014;6:105-17. PMID: 24623991 DOI: $10.2147 /$ CMAR.S32380

Santos RR, Rodrigues APR, Costa SHF, Matos MHT, Silva JRV, Celestino JJH, Martins FS, Saraiva MVA, Melo MAP, Figueiredo JR. Teste de toxicidade e criopreservação de folículos pré-antrais ovinos isolados utilizando Glicerol, Etilenoglicol, Dimetilsulfóxido e Propanodiol. Braz J Vet Res Anim Sci. 2006;43:250-5. DOI: 10.11606/issn.1678-4456.bjvras.2006.26506

Santos JT, Silva-Santos KC, Andrade ER, Lisboa LA, Schneider CL, Ciquini A, Ferreira R, Nóbrega Junior JE, Seneda MM. Effect of fixative type and fixation time on the morphology of bovine preantral ovarian follicles. Semina: Ciênc Agrárias. 2012;33:297-304. DOI: 10.5433/1679-0359.2012v33n1p297

Saraiva MVA, Matos MHT, Faustino LR, Celestino JJH, Silva JRV, Figueiredo JR. Pituitary hormones and their role in folliculogenesis. Rev Bras Reprod Anim. 2010;34:206-21.

Scalercio SRRA, Santana LDNS, Domingues SFS, Amorim CA, Santos RR. Transplante ovariano: Destaques na reprodução de primatas não humanos. Acta Sci Vet. 2015;43:1-2.

Schunemann E Jr, Souza RT, Dória MT, Spautz CC, Urban CA. Oncofertility: fertility considerations in the management of gynecological cancer. Femina. 2011;39:485-91.
Silva JMM. Avaliação de ovários criopreservados por vitrificação ou congelação lenta após intervalo precoce e tardio de castração em ratas [Thesis]. Departamento de Cirurgia. Fortaleza: Universidade Federal do Ceará. Faculdade de Medicina; 2014. Available at: http://www. repositorio.ufc.br/bitstream/riufc/8323/1/2014_tese_ jmmsilva.pdf. Accessed: 19/12/2017.

Sonmezer M, Oktay K. Fertility preservation in female patients. Hum Reprod Update. 2004;10:251-66. PMID: 15140872 DOI: $10.1093 /$ humupd/dmh021

Suzuki N, Yoshioka N, Takae S, Sugishita Y, Tamura M, Hashimoto S, Morimoto $Y$, Kawamura K. Successful fertility preservation following ovarian tissue vitrification in patients with primary ovarian insufficiency. Hum Reprod. 2015;30:608-15. PMID: 25567618 DOI: 10.1093/humrep/deu353

Thomaz BAC, Biondo-Simões MLP, Almodin CG, Minguetti-Camara VC, Ceschin AP, Ioshii SO. Histological aspects of rabbit ovarian tissue after cryopreservation. Rev Bras Ginecol Obstet. 2005;27:642-9. DOI: $10.1590 /$ S0100-72032005001100002

Van der Poel SZ. Historical walk: The HRP special programme and infertility. Gynecol Obstet Invest. 2012;74:218-27. PMID: 23146951 DOI: 10.1159/000343058

Wang Y, Xiao Z, Li L, Fan W, Li SW. Novel needle immersed vitrification: a practical and convenient method with potential advantages in mouse and human ovarian tissue cryopreservation. Hum Reprod. 2008;23:2256-65. PMID: 18614614 DOI: $10.1093 /$ humrep/den255 